\title{
水の入った円筒タンクに生起する非線形振動応答 NONLINEAR OSCILLATION RESPONSE OF A CYLINDRICAL TANK WITH WATER
}

\author{
皆川洋一* \\ Youichi MINAKAWA
}

\begin{abstract}
Cylindrical shell tanks with water on a shaking table driven with sinusoidal excitation show various nonlinear responses. In order to make clear some causes of the response, we have been examining the system on both theoretical and experimental aspects. Here, basing upon experimental vibration tests of the tank, we show the nonlinear responses higher-harmonic oscillations and sub-harmonic oscillations. Various sub-harmonic oscillations branched out on some frequency regions and became significant responses with large amplitudes. Then, focusing the sub-harmonic responses, we examine relation the instability regions and the natural frequencies of the system, plotted for external frequency and the amplitude.
\end{abstract}

keywords: cylindrical tank, nonlinear oscillation, sub-harmonic oscillation, out-of-round mode, test on shaking table

\section{§1はじめに}

水の入った円筒タンクの振動問題はふたつの側面から研究されてい る。ひとつは剛な容器に入った自由表面を有する水が振動するスロッシ ング振動問題を検討するもので、振動数の小さな外力振動数の下での応 答が研究対象となる。他方は水の入ったタンクの振動を扱う問題であ り、振動数が比較的大きな外力振動数の下での容器の振動現象が研究対 象となる。振動台の上で、周期的な外力を受けると、水の入った円筒夕 ンクに線形振動からは予測できない応答が観測される。Clough等"1円 筒タンクの振動実験を行ない、応答に円筒の断面が変形する (out-ofround）高次振動モードが観測されること、線形振動理論に基づいてこ のような応答が発生する現象を説明することはできないこと、円筒タン クに存在する初期不整がこの高次振動モードの応答を生起させる要因で あることを報告している。

水の入ったタンクの解析的な研究は、液体を換算質量に置換する方法 を適用して遂行されていた。近年、液体をポテンシャル流体としてモデ ル化し、この流体と弾性体容器との動的相互作用問題として定式化する 方法が適用されている。これに基づいた線形理論の解析が行われ、工学 的に有用な知見が報告されている2,3)。

円筒の断面が変形する振動モードの応答は幾何学的非線形性に由来す ると推察し、著者等は周期的な外力を受ける円筒シェル容器の水平振動
実験を継続してきた。非線形応答であることを確認するために、線形振 動理論による解析と比較( し、応答を各振動成分每、および円筒の周方 向の各フーリエ級数展開次数每の振幅に分析し、周方向展開次数が 2 以 上の振動モードを有する高調波振動や分数調波振動の応答曲線12,200を報 告して来た。また、著者はタンクの弾性変形に伴う流体場の変化を考虑 する定式化を示し、実験供試体に観察される非線形振動応答の生起が定 性的には説明6,14)できることを示した。

非線形振動応答が出現する要因、生起する振動数領域、および振動の 大きさについて定性的な知見を得るためには、詳細に実験を行う必要が ある。線形振動は外力の大きさに比例する応答量を示す。しかしなが ら、非線形振動は、振動の生起が外力の大きさに依存し、外力の大きさ と応答量に線形の関係が成立しない。複数の振動モードが関倸する非線 形振動において、同じような手続きで作製された供試体のわずかな固有 振動数の相違に依存して、生起する振動現象に差異が観察される。ここ では、異なる供試体を利用し、水の量、および外力加速度の大きさ等を パラメータとした実験から得られた非線形振動応答15-17)の概要を示し、 タンクに大きな影響を与える分数調波振動応答の発生する不安定領域と その生起要因を分析する。これらは円筒タンクの応答を精動に検討する 上での重要な知見となる。 

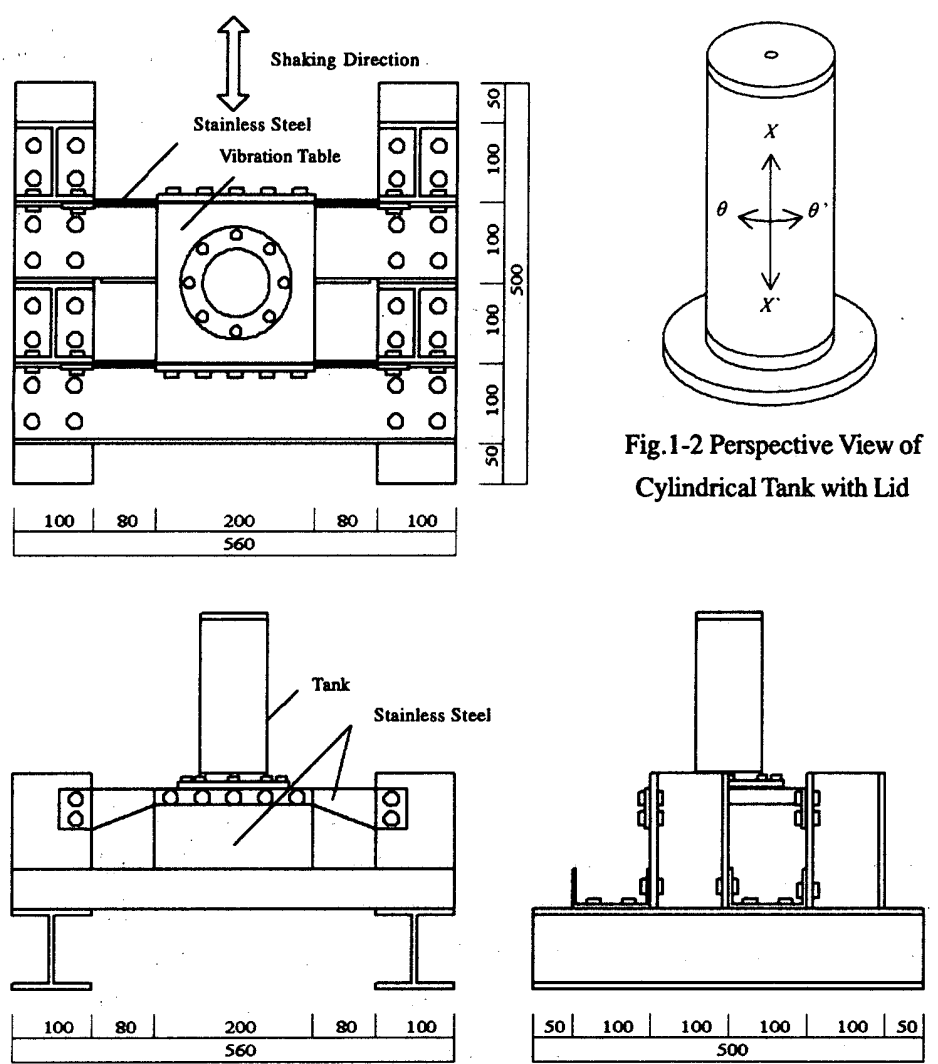

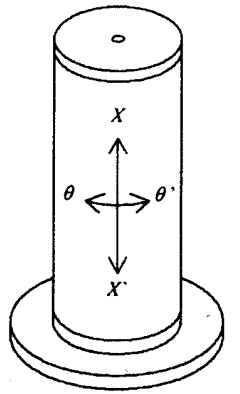

Fig.1-2 Perspective View of Cylindrical Tank with Lid
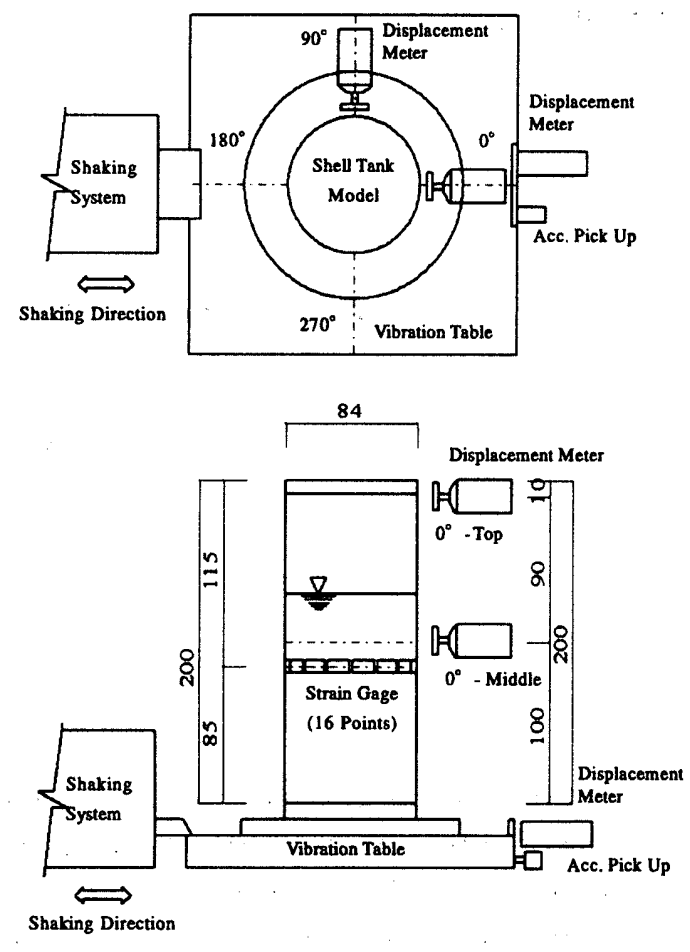

Fig.1-3 Tank and Measuring Devices

Fig.1-1 Cylindrical Tank on Shaking Table

\section{§ 2 実験装置とデータ処理}

\section{2-1 実験装置と測定}

振動実験装置は電磁式の加振器 (最大加振力 $45.3 \mathrm{~kg}$ )、寸法 $200 \mathrm{~mm} \times$ 200mmの振動台、および測定装置から構成されている(Fig.1-1)。振動台 は可動方向の両端部に配置されたT型のステンレス板(厚さ0.5mm)を用 いて取り付けられ、上下方向と直交方向への移動が拘束されている。円 筒部は直径約 $84 \mathrm{~mm}$ 、高さ $200 \mathrm{~mm}$ であり公称厚さ $0.5 \mathrm{~mm}$ の㙁化ビニール・ フィルムを用いて作られた。この円筒シェルの頂部にアクリル板のフタ (厚さ8mm)を持つ円筒タンク模型を作制した(Fig.1-2)。塩化ビニール・ フィルムののりしろは4-8mmとし、シアノアクリレート系の接着剤を用 いて接合された。円筒シェルはアルミニウム製の基盤に取付けられ、振 動台に8本のM8ボルトを用いて接合された。塩化ビニール・フィルム とアクリル板のフタおよびアルミニウム製の基盤とはエポキシ樹脂系の 接着剂を用いて接合された。また、アクリル板のフタの中央に直径 $8 \mathrm{~mm}$ の穴を空け、水の注入、および排出に利用した。

振動台の振動数 $\omega$ を円振動数 (単位: $\mathrm{rad} / \mathrm{sec}$ )、または振動数 (単位: $\mathrm{Hz}$ ) $(=\omega / 2 \pi)$ として表現する。变位は電磁容量の変化を利用する非接触型 の変位計を用いて、3箇所で測定された。それらは、振動台の加振方向 $(\theta=0$ 度) タンクの底から高さ $190 \mathrm{~mm}$ の位置、および $100 \mathrm{~mm}$ の位置、加 振方向と直角 ( $\theta=90$ 度)の位置にあるタンクの底から高さ $100 \mathrm{~mm}$ の位 㯰におけるタンクの法線方向の変位(Fig.1-3)である。変位計の測定精度 は1/1000mm程度である。円筒シェルの周方向の振動応答モードを特定 するために、タンクの底から高さ85 mmの位置において円筒シェル表面 の周方向に16枚のひずみグージ(ベース剛性の小さなプラスチック用 のもの)が貼付され、周方向のひずみ応答が測定された(Fig.1-3)。非線 形振動の生起に系の減衰特性が影響するものと予測されるものの、ここ では减衰量を測定していない。

\section{2-2 データの収集と処理}

実験の応答はパーソナル・コンピュータ(PC9801-EX:CPU80286)を利 用したAD変換器を用いてディジタル量として測定され、即座にキャリ ブレーション・データを用いて变換された。具体的に示せば、このパソ コンに1枚で16チャンネルを有するAD変換ボードが3枚 (PCN-2098:1 枚, PCN-2198:2枚, N電子)取付けられ、サンプリングのチャンネル数、お よび時間間隔はアセンブリ言語を用いソフトウェア的に制御された。こ の結果、各AD変換器の任意の順番てで読み取られたデータと1番目に読 み取られたデータとの間に存在する時間遅れは正確に算定された。1 番目 にPCN-2098、2および3番目にPCN-2198のAD変換ボードを用い、順に $\mathrm{AD}$ 変換命令を与える。3枚のボードの変換が終わるまでマシン語の LOOPを回して時間待ちを行ない、変換されたデータをメモリに収納し た後、1,2,3番目のAD変換ボードに再度変換命令を与える。このような 揁作を $n_{s}\left(1 \leqq n_{s} \leqq 16\right)$ 回行なうと $3 n_{s}$ 個のデジタル・データを得ること ができる。ここで利用した読み取りプログラムでは1番目と 2 番目、お よび2番目と3番目のボードの時刻遅れはそれぞれ0.00451 msec、および $0.00161 \mathrm{msec}$ であった。3枚のボードのAD変換、およびデータの収納に かかる時間 $\Delta \mathrm{t}_{1}$ は0.0368msecであった。また、この時刻のサンプリング プログラムの終了手続き、およびサンプリング時間間隔を調整するLOOP を $n$ 回とすると、この時間は次式のように表される。

$\Delta t_{2}=0.00292+0.00102 n_{1}(\mathrm{msec})\left(1 \leqq n_{1} \leqq 65535\right)$ 故に、 $3 n_{s}$ 個のデータのサンプリングが完了するまでの時間、すなわちサ ンプリングの時間間隔 $\Delta$ は土次式のように表される。

$$
\Delta t=n_{s} \Delta t_{1}+\Delta t_{2}
$$

同一の正弦波振動をこれらのボードを用いて測定し、得られた波形の 位相遅れを测定して、これらの時間遅れは算定された。 
2-3 データの有限フーリエ級数表示

2-3-1 有限フーリエ級数表示

サンプリング時間間隔を $\Delta t$ とし、サンプリング個数を $M=2 n(n$ : 任意 の整数) とし、得られるデータ $X_{m}(m=0,1,2 \ldots M-1)$ を次のように表す。 $X_{m} \div \frac{1}{2} A_{0}+\sum_{k=1}^{M / 2-1}\left(A_{k} \cos \frac{2 \pi k m}{M}+B_{k} \sin \frac{2 \pi k m}{M}\right) \quad(m=0,1, \ldots, M-1)$ $A_{k}=\frac{2}{M} \sum_{m=1}^{M} X_{m} \cos \frac{2 \pi k m}{M}(k=0,1, M / 2)$,

$B_{k}=\frac{2}{M} \sum_{m=1}^{M-1} X_{m} \sin \frac{2 \pi k m}{M}(k=0,1, M / 2-1)$

これらのデータは有限フーリエ級数を用いて次式のように表される。 $X(t) \div \frac{1}{2} A_{0}+\sum_{k=1}^{M / 2-1}\left(A_{k} \cos \frac{2 \pi k t}{M \Delta t}+B_{k} \sin \frac{2 \pi k t}{M \Delta t}\right)$

ここに、 $t=m \Delta t$.

2-3-2 測定パラメータと読み取りに伴う時間遅れの修正

外力の円振動数 $\omega(\mathrm{rad} / \mathrm{s})$ とするとき、外力周期 $T(=2 \pi / \omega)$ の 倍 の時間を $M(=2 n ; n$ は整数 $)$ 等分した時間間隔でデータを収集する。

$\Delta t=p T / M=2 \pi p /(\omega M)$

読み取られたデータは高速フーリエ変換(FFT)を利用して直ちに有限 フーリエ・スペクトルに分解される。各データがAD変換された時刻の 相対的な時間間隔は算定されているので、応答が周期的であることを仮 定すれば各データのサンプリングに伴う時間遅れを補正し、各チャンネ ルのデータが一時に収集されたデータであるように修正することができ る。この方法を示す。各測定点 $i$ の $m$ 個のデータ $D_{i m}(m=0,1, \ldots M-1)$ を 有限フーリエ級数表示すれば、(1)式と同様に、次式のように表現される。

$$
\begin{gathered}
D_{(}(\tau) \div \frac{1}{2} A_{0}^{\prime}+\sum_{k=1}^{M / 2-1}\left(A_{i k}^{\prime} \cos \frac{k \omega \tau}{p}+B_{i k}^{\prime} \sin \frac{k \omega \tau}{p}\right) \\
A_{i k}^{\prime}=\frac{2}{M} \sum_{m=1}^{M} D_{i m} \cos \frac{2 \pi k m}{M}(k=0,1, M / 2), \\
B_{i k}^{\prime}=\frac{2}{M} \sum_{m=1}^{M} D_{i m} \sin \frac{2 \pi k m}{M}(k=0,1, M / 2-1)
\end{gathered}
$$

実験において、単一の円振動数 $\omega$ を有する正弦波、あるいは余弦波を 用いて、振動台を振動させた。外力振動数と応答の位相のずれを把握し 易いように、円振動数 $\omega$ を有する振動台の変位応答は余弦関数として表 されるように時間軸を変更する。余弦関数と表現するときの時刻 $t$ 実 験での測定時刻との時間遅れを $\phi$, と表現する。このとき、各測定点 $の$ 湘定時刻と振動台との時間遅れを $\Delta \tau$ ，とすれば、次式が成立する。

$$
t=\tau+\Delta \tau_{i}+\phi_{1}
$$

ただし、時間遅れ $k=p$ の関数が余弦関数の正のフーリエ係数を有し、正弦波の係数はゼロ となる次式を満たす条件から定められる。

$A_{1 p}^{\prime} \cos \omega \phi_{1}+B_{1 p}^{\prime} \sin \omega \phi_{1} \geq 0, A_{1 p}^{\prime} \sin \omega \phi_{1}-B_{1 p}^{\prime} \cos \omega \phi_{1}=0$

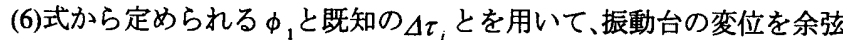

\begin{tabular}{|c|c|c|c|c|c|c|c|c|c|}
\hline \multirow{2}{*}{$\begin{array}{l}\vec{d} \\
\dot{\Sigma}\end{array}$} & \multicolumn{2}{|c|}{$\begin{array}{c}\text { Vinyl } \\
\text { Chloride Film }\end{array}$} & \multicolumn{3}{|c|}{$\begin{array}{l}\text { Cylindrical Shell } \\
(\mathrm{mm})\end{array}$} & \multicolumn{4}{|c|}{$\begin{array}{c}\text { Mass of Shell } \\
(\mathrm{kg})\end{array}$} \\
\hline & $\begin{array}{c}\text { Thick } \\
\text {-ness } \\
\text { (mm) }\end{array}$ & $\begin{array}{c}E \\
(\mathrm{GPa})\end{array}$ & $\begin{array}{l}\text { Diar } \\
\text { meter }\end{array}$ & Height & $\begin{array}{c}\text { Over } \\
\text {-lap } \\
\text { Width }\end{array}$ & Shell & $\begin{array}{l}\text { Acrylic } \\
\text { Lid }\end{array}$ & $\begin{array}{l}\text { Alumi- } \\
\text { num } \\
\text { Base }\end{array}$ & $\begin{array}{l}\text { Total } \\
\text { Mass }\end{array}$ \\
\hline Mv1 & 0.51 & 3.38 & 83.7 & 200 & 4 & - & - & - & - \\
\hline Mv2 & - & - & 84.3 & 200 & - & 0.0420 & 0.0518 & 0.539 & 0.633 \\
\hline Mv3 & 0.51 & - & 84.1 & 200 & 5 & 0.0412 & 0.0541 & 0.531 & 0.627 \\
\hline Mv4 & - & - & 84.2 & 200 & 5 & 0.0405 & 0.0512 & 0.538 & 0.651 \\
\hline Mv5 & 0.509 & 3.19 & 84.3 & 200 & 5 & 0.0391 & 0.0540 & 0.554 & 0.662 \\
\hline Mv6 & 0.509 & 3.19 & 83.8 & 200 & 5 & 0.0375 & 0.0528 & 0.537 & 0.643 \\
\hline Mv7 & 0.51 & 3.14 & 84.5 & 200 & 5 & 0.0384 & 0.0527 & 0.589 & 0.697 \\
\hline Mv8 & 0.51 & 3.14 & 84.4 & 200 & 7 & 0.0385 & 0.0521 & 0.565 & 0.675 \\
\hline
\end{tabular}
波として表現した時刻 $t$ を利用すると、各測定点 $i$ 応答は次式のよう に表わされる。

Table.1 Material Properties, Size and Weight of Cilindrical Tanks

$$
\begin{gathered}
D_{i}(t)=\frac{A_{i 0}}{2}+\sum_{k=1}^{M n_{-}}{ }^{\prime}\left(A_{i k} \cos \frac{k \omega t}{p}+B_{i k} \sin \frac{k \omega t}{p}\right) \\
A_{i k}=A_{i k}^{\prime} \cos \frac{k \omega}{p}\left(\Delta \tau_{i}+\phi_{1}\right)-B_{i k}^{\prime} \sin \frac{k \omega}{p}\left(\Delta \tau_{i}+\phi_{1}\right)(k=0, \ldots, M / 2-1) \\
B_{i k}=A_{i k}^{\prime} \sin \frac{k \omega}{p}\left(\Delta \tau_{i}+\phi_{1}\right)+B_{i k}^{\prime} \cos \frac{k \omega}{p}\left(\Delta \tau_{i}+\phi_{i}\right)
\end{gathered}
$$

応答実験時に測定パラメータ $p=6$ とし、外力振動数が $360 \mathrm{~Hz}$ 以下の領 域において $M=64 、 361 \mathrm{~Hz}$ 以上の領域では $M=32$ とした。

2-3-3 円筒シェルの振動におけるモードの解析

振動台の変位を余弦関数とする時刻軸の変更を行なったとき、円筒 シェル周方向のひずみ応答 $\varepsilon_{\mu}(\mu=0,1, \ldots N-1)$ は次式のように表される。 $\varepsilon_{\mu}(t)=\frac{\alpha_{\mu 0}}{2}+\sum_{k=1}^{M / 2}{ }^{-1}\left(\alpha_{\mu k} \cos \frac{k \omega t}{p}+\beta_{\mu k} \sin \frac{k \omega t}{p}\right) \quad(\mu=0,1, \ldots, N-1)$ 有限フーリエ級数を利用して、(8)式の $N$ 個のデータを表す。

$\delta(\theta, t)=\frac{1}{2}\left\{\frac{1}{2} Q_{\infty 0}^{c}+\sum_{\nu=1}^{N / 2}-1\right.$

$+\sum_{k=1}^{M R-1}\left[\left\{\frac{1}{2} Q_{k 0}^{c}+\sum_{v=1}^{N R-1}\left(Q_{k v}^{c} \cos v \theta+Q_{k}^{s} \sin v \theta\right)\right\} \cos \frac{k \omega x}{p}\right.$

$\left.+\left\{\frac{1}{2} R_{k 0}^{c}+\sum_{v=1}^{N / 2}\left(R_{k v}^{c} \cos v \theta+R_{k v}^{s} \sin v \theta\right)\right\} \sin \frac{k \omega t}{p}\right]$

$$
\begin{aligned}
& Q_{k v}^{c}=\frac{2}{N} \sum_{\mu=1}^{N} \alpha_{\mu k} \cos \frac{2 \pi v \mu}{N}, Q_{k v}^{s}=\frac{2}{N} \sum_{\mu=1}^{N} \alpha_{\mu k} \sin \frac{2 \pi v \mu}{N} \\
& \text { ここに、 } \quad R_{k v}^{c}=\frac{2}{N} \sum_{\mu=1}^{N} \beta_{\mu k} \cos \frac{2 \pi v \mu}{N}, R_{k v}^{s}=\frac{2}{N}{ }_{j=1}^{N} \beta_{\mu k}^{\prime} \sin \frac{2 \pi v \mu}{N}
\end{aligned}
$$

円筒シェルの周方向に等間隔で設置した $N$ 個のセンサーから得られた 測定データを用いて、円筒底部から $85 \mathrm{~mm}$ の位置のひずみ応答における 周方向展開次数（振動モード）が分析される。ここでは $N=16$ として、 応答における周方向展開次数 $v=0$ から7までのモードを分析する。

\section{2-3-4 応答曲線の表現方法}

表現する応答曲線の数を少なくするために、变位応答は次式で表され る各振動成分の振幅と外力振動数 $(\mathrm{Hz})$ の関係として表現する。

$$
d_{i k}=\sqrt{\left(A_{i k}\right)^{2}+\left(B_{i k}\right)^{2}}(k=1, \ldots, M / 2-1)
$$

円筒タンクの周方向のひずみも各振動成分に対応する各周方向フーリ エ展開次数に対応する振動モードの振幅の2乗平均値にこの後、ひずみ の振幅と表現する)と外力振動数 $(\mathrm{Hz})$ の関係として表現する。

$$
\begin{aligned}
& \varepsilon_{k v}=\sqrt{\left(Q_{k v}^{c}\right)^{2}+\left(Q_{k v}^{s}\right)^{2}+\left(R_{k v}^{c}\right)^{2}+\left(R_{k v}^{s}\right)^{2}}(v=1, \ldots, N / 2-1 ; k=1, \ldots, M / 2-1)(11-\mathrm{a}) \\
& \varepsilon_{00}=Q_{00}^{c} / 4
\end{aligned}
$$

外力振動数は $k=p$ に対応する。外力振動数の $\mu(=k / p)$ 倍の振動数を有 する振動成分は $\mu=1$ のとき基本振動成分、 $\mu か ゙ 2$ 以上の整数のとき $\mu$ 倍 の高調波振動成分、 $\mu$ が分数のとき $k / p$ 倍の分数調波振動成分と呼ぶ。 変位応答、およびひずみ応答はこれら振動成分毎に分析される。これら 振動成分毎に、周方向展開次数 $v$ 対応するひずみ応答曲線が描かれ る。応答を検討する次節以降において、周方向展開次数を $N$ と表現す る。また、測定のパラメータ $p$ 、及びMに依存して、振動成分の分解 能力が変化する。ここでは、2-3-2に示した $p 、 M$ 値を用いた。

\section{§3 実験において覾測された応答}

3-1 供試体

実験に利用された供試体は8体ある。それらをMvi $(i=1, \cdots, 8)$ と表現す る。ほぼ同一になるように作製されたこれらの供試体の主な寸法、円筒 シェルの素材である㙁化ビニール・フィルム(公称厚さ $0.5 \mathrm{~mm})$ の材料特 性、のりしろ幅、重量等を表1に示す。表中の記号-は測定されたデー タが残っていないことを表わす。フタは初期不整の小さな供試体を作製 し、実験中に水があふれることを防止する目的で取り付けられた。この ため、周方向展開次数 $\mathrm{N} \neq 1$ の振動モードの最小固有振動はタンクの 上下端部で変位が拘束されたモードとなる。 


\section{3-2：水の入った円筒タンクの応答概要}

水の入った円筒タンクの水平振動応答の概括的な挙動を示す。供試体Mv6の 水高 $130 \mathrm{~mm}$ をモデル15)とする。外力振動数を $30 \mathrm{~Hz}-540 \mathrm{~Hz}$ の領域において変化

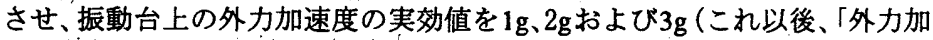
速度 $1 \mathrm{~g} 、 2 \mathrm{~g}$ および $3 \mathrm{~g}$ 」表現する）として得られた各周方向展開次数に分解 されたひずみ応答の振幅 ((11)式)を用いる。

\section{3-2-1 基本振動成分の応答}

基本振動成分の各周方向展開次数 $\mathrm{N}(=0,1, \ldots, 7)$ に对応するひずみ応答曲線

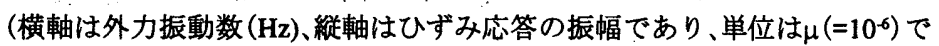
ある)をそれぞれFig.3-1に上から順制に示す。図中の記号O、、、および口は

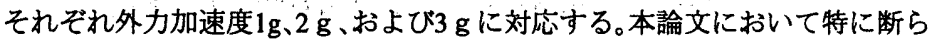
ない限り、応答曲線の記号と対応する外力加速度にこれらの表現を用いる。周 方向展開次数 $\mathrm{N}=0,1,2,3,4,5,6,7$ に対応する最小固有振動数がそれぞれ $231 \mathrm{~Hz}, 144 \mathrm{~Hz}, 162 \mathrm{~Hz}, 118 \mathrm{~Hz}, 124 \mathrm{~Hz}, 172 \mathrm{~Hz}, 254 \mathrm{~Hz}, 352 \mathrm{~Hz}$ であると算定された。大域的 には、外力加速度に比例して振幅が増大する応答が観察される。これらは線形

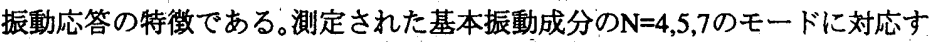
るひずみ応答の最大振幅は約 $450 \mu$ である。

\section{3-2-2 分数調波振動応答}

1/3倍分数調波振動成分、および $1 / 2$ 倍分数調波振動成分の各周方向展開欧数 $\mathrm{N}(=0,1, \ldots, 7)$ に対応するひずみ応答曲線をそれぞれFig.3-2、およびFig.3-3に示 す。分数調波振動は大域的に観察すると生起しない応答であるが、ある特定の 外力振動数の下で分岐する形で発生し、大きな振幅の振動となる。外力加速度

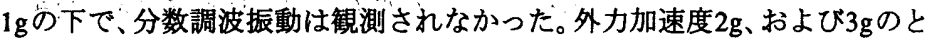
き、分数調波振動応答が出現した。

外力振動数 $380 \mathrm{~Hz}$ 近傍に1/3倍分数調波振動、および1/2倍分数調波振動が 共に分岐している。N=5、およひ $\mathrm{N}=6$ に対応するモードの $1 / 2$ 倍分数調波振動、 およびN=5のモードの1/3倍分数調波振動が主となる応答を示す。外力振動数 506Hz近傍にはN=6のモードの1/2倍分数調波振動が主となる応答が分岐する。

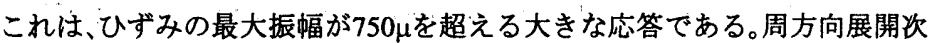
数 $\mathrm{N}=6$ を有するこの振動モードは $1 / 2$ 倍分数調波振動であるから、外力振動数 が506Hzのとき $253 \mathrm{~Hz}$ の振動数を有する。前節で示したように、 $\mathrm{N}=6$ モードの 最小固有振動数は $254 \mathrm{~Hz}$ である。分岐した $1 / 2$ 倍分数調波振動はこの最小固有 振動数に対応する。この1/2倍分数調波振動が出現する領域 (1/2倍分数調波 振動の不安定領域)の一部の領域に $\mathrm{N}=4$ のモードの $1 / 3$ 倍分数調波振動が生起 する領域 (1/3倍分数調波振動の不安定領域) が観察された。外力加速度 $3 \mathrm{~g}$ の 応答において、連続的に変化しない忘答曲線が観測された。これは水が滴と なって、表面から飛び出す現象が起こっていることに対応する。

一方、外力振動数 $350 \mathrm{~Hz}$ 近傍に $=5$ に対応するモードの $1 / 2$ 倍分数調波振動

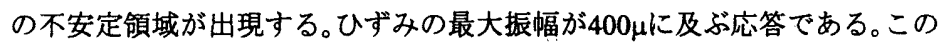
振動の振動数はN=5の振動モードの最小固有振動数 $172 \mathrm{~Hz}$ とほぼ一致する。分 岐した $1 / 2$ 倍分数調波振動は、この最小固有振動数に対応する振動数、および 振動モードを有する。この領域では、1/3倍分数調波振動は観測されなかった。

\section{3-2-3 高調波振動応答}

2倍高調波振動の各周方向展開次数 $\mathrm{N}(=0,1, \ldots, 7)$ に対応するひずみ応答曲線 をFig.3-4に示す。各周方向展開次数の最小固有振動数の1/2倍の外力振動数の 下で、2倍高調波振動応答が大きな振幅を示す。周方向展開次数 $\mathrm{N}=1,5,6$ の一

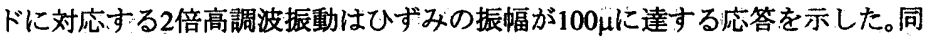

畔泎 それぞれ(11)式の $\varepsilon_{00}$ ，および $\varepsilon_{k N}$ に対応する。p=6(2-3-2節)としているので， 基本振動成分は 2-3-3 節に示したように $k=6$ に対応する。
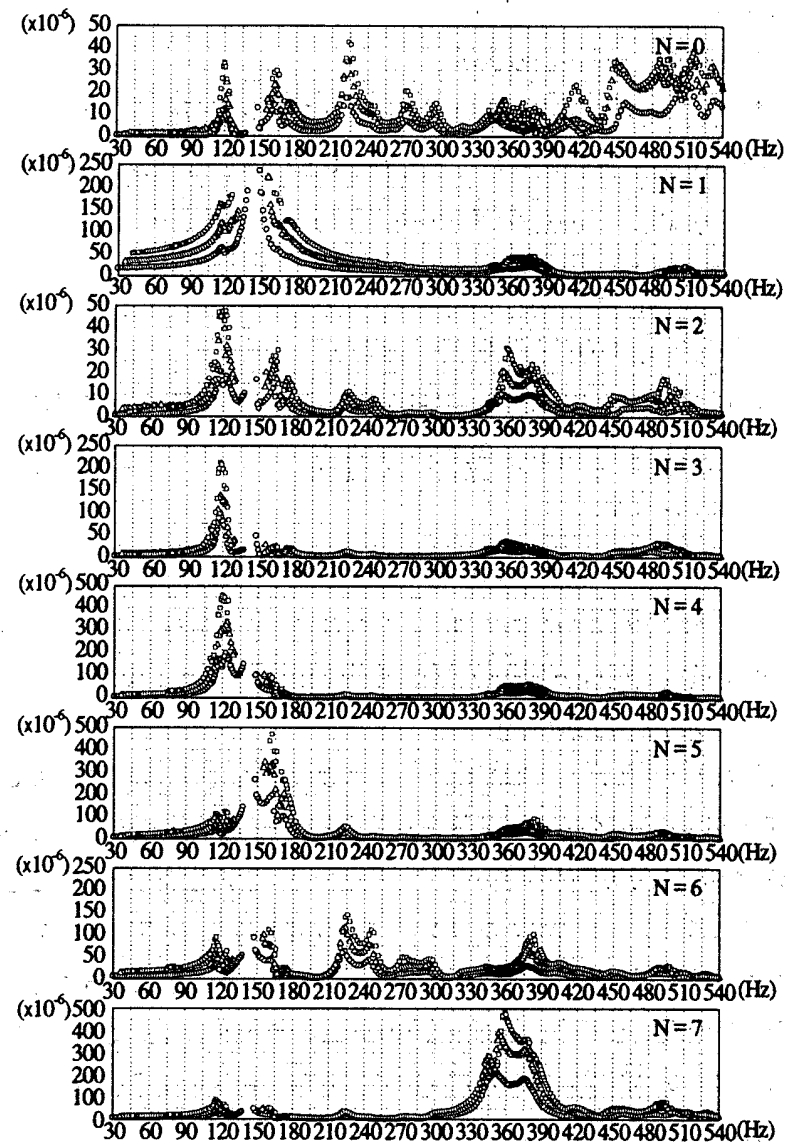

Fig.3-1 Strain-Frequency for each $\mathrm{N}$ of the Fundamental Oscillation Component

(Mv6, Water Height 130mm , Acceleration 1.0,2.0,3.0g)

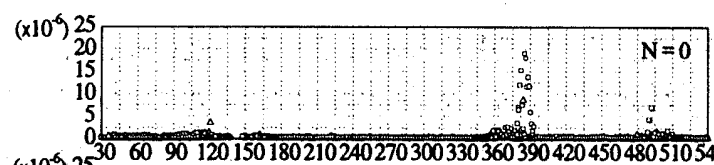

$$
(x 10
$$

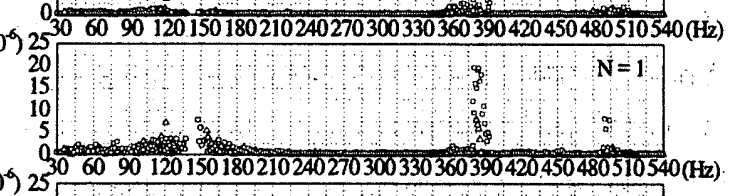

$\left(\times 10^{-6}\right) 25$

20
15
10
5

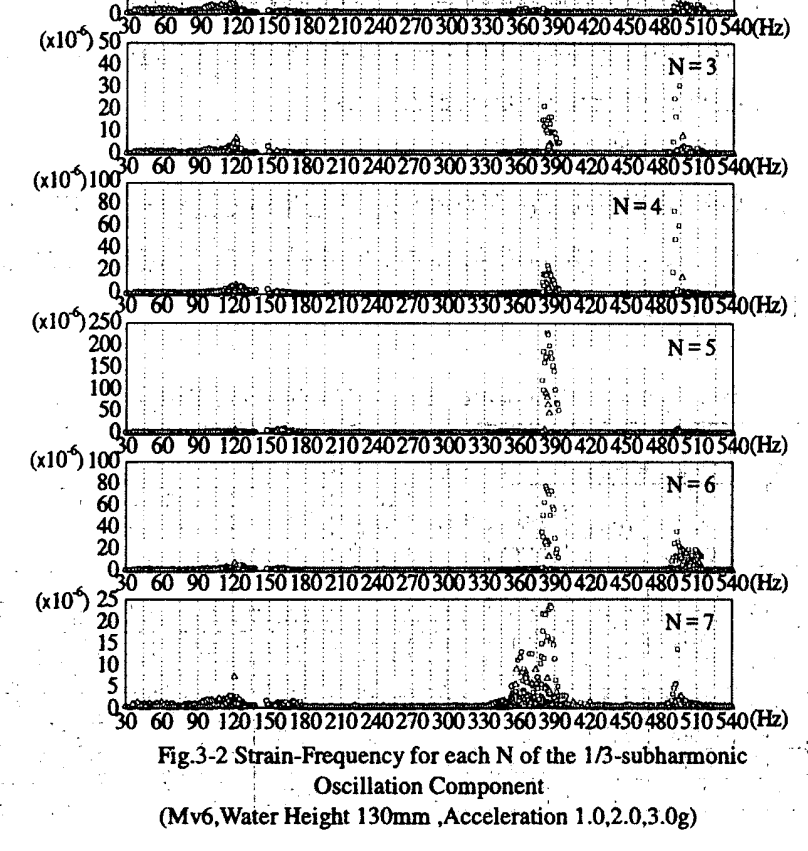


$\left(\times 10^{-6}\right)$

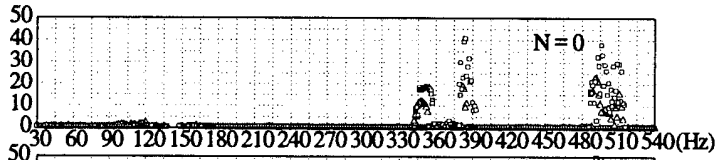

$\left(\times 10^{-5}\right)$ $506090120150180210240270300330360390420450480510540(\mathrm{~Hz})$

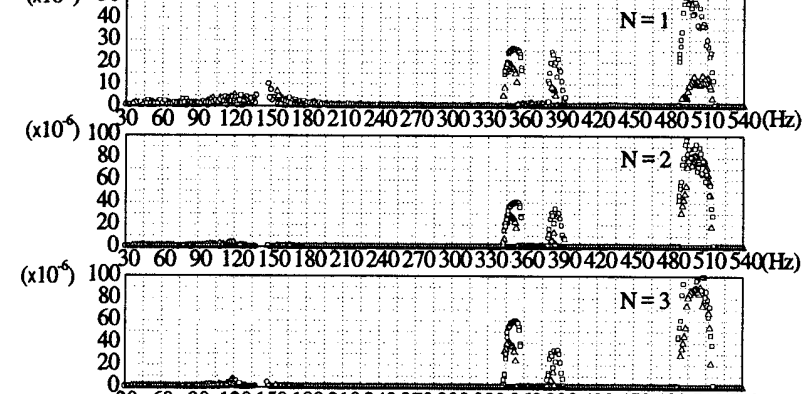
(x10 $100^{30} 6090120150180210240270300330360390420450480510540(\mathrm{~Hz})$

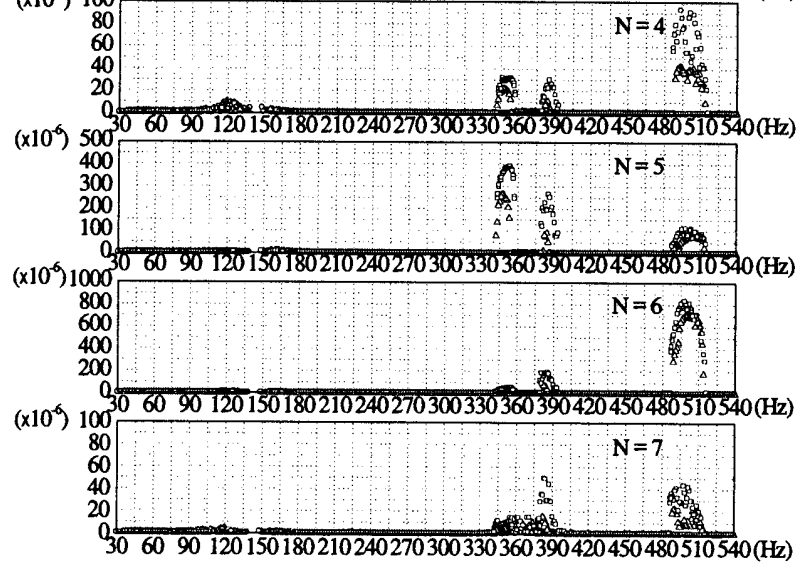

Fig.3-3 Strain-Frequency for each $\mathrm{N}$ of the 1/2-subharmonic Oscillation Component

(Mv6,Water Height 130mm ,Acceleration 1.0,2.0,3.0g)
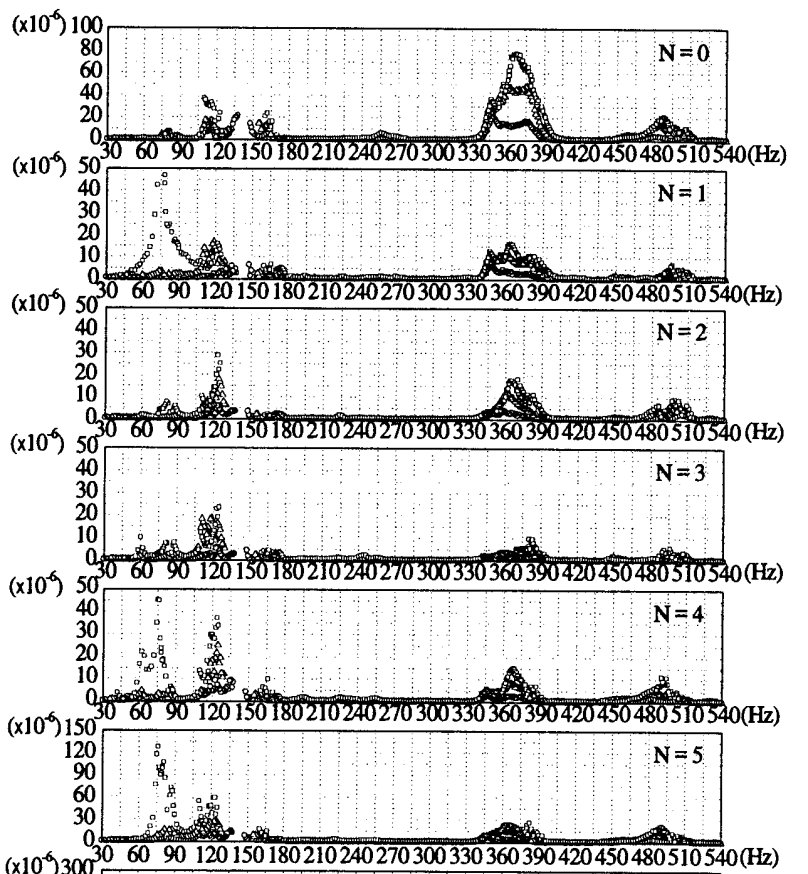
$\left(\times 10^{-6} 300^{306090120150180210240270300330360390420450480510540(\mathrm{~Hz})}\right.$
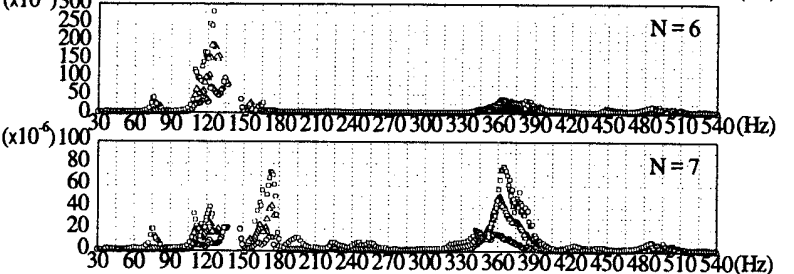
$\left(x 10^{-6}\right) 100$

Fig.3-4 Strain-Frequency for each $\mathrm{N}$ of the 2 nd-harmonic Oscillation Component

(Mv6, Water Height 130mm ,Acceleration 1.0,2.0,3.0g)

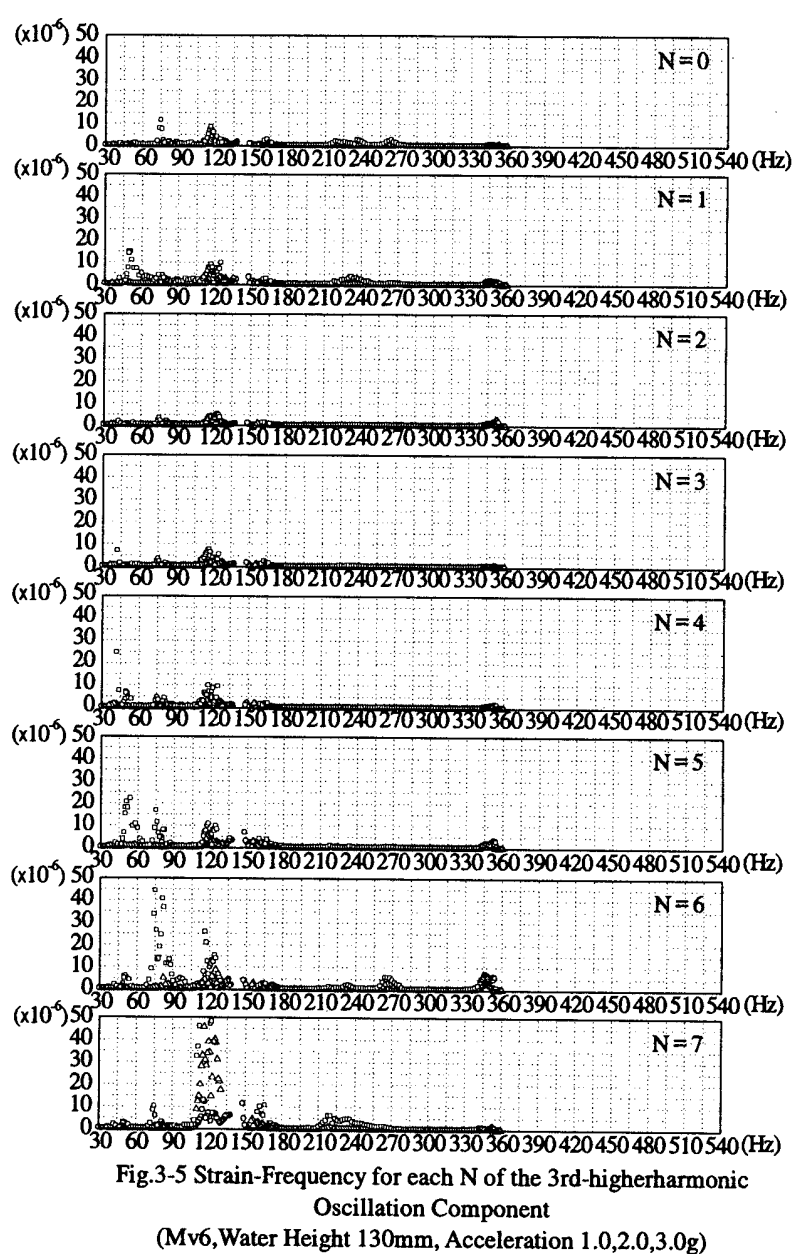

様に、3倍高調波振動の各周方向展開次数 $\mathrm{N}(=0,1, \ldots, 7)$ に対応するひずみ応答曲 線をFig.3-5に示す。各周方向展開次数の最小固有振動数の1/3倍の外力振動数 の下で、3倍高調波振動成分の忘答が増大した。これらの高調波振動の応答曲 線は振幅が漸增する形で振幅が変化する。測定のパラメータ $M=32$ とした (23 節) ことに伴い、応答に含まれる 3 倍高調波振動成分 $(k=3 \times 6=18)$ が分析で きなくなった。

\section{$\S 4$ 系の固有振動数と分数調波振動の不安定領域}

分数調波振動はある加速度以下の外力の下では生起しない非線形振動であ る。ある供試体において観測された分数調波振動が、同様に作製された他の供 試体において生起しないこともある。応答実験で観測された分数調波振動につ いて、系の固有振動数と分数調波振動の不安定領域の振動数との関係、および 出現した分数調波振動の主な振動モードに対応するひずみ応答振幅を示す。 4-1 水高をパラメータとした応答

\section{4-1-1 固有振動数 $(\mathrm{Hz})$ の特定}

タンクの水量を底からの水の高さ(水高)として表現する。水高をパラメー タとした供試体 Mv7 の実験応答 17 ) から特定された周方向展開次数 $\mathrm{N}=$ 0,1,2,3,4,5,6,7の各振動モードに対応する最小固有振動数 $\omega_{\mathrm{N} 1}(\mathrm{~Hz})$ をFig.4-1に示 す。大きな白抜き記号は実験から特定された振動数、小さな記号は有限要素法 14)を用いて解析された固有振動数 $(\mathrm{Hz})$ である。この解析において、円筒シェ ル、およびフタは合計26個の円錐台要素、および流体は水高に応じ最大 150 個 の三角形リング要素を用いたメッシュにモデル化された。塩化ビニル・フィル ムのポアソン比 0.35 、質量密度 $1.38 \times 10^{3} \mathrm{~kg} / \mathrm{m}^{3}$ を採用した。アクリルのフタの ヤング率3.34GPa、ポアソン比 0.35 、質量密度 $1.22 \times 10^{3} \mathrm{~kg} / \mathrm{m}^{3}$ を用いた。その他 の定数はTable1の值を利用した。 
水高が70mm以下のとき、記号○を付けた周方向展開次数 $\mathrm{N}=1$ の振動 モードがこの系の最小固有振動数となる。この領域において、水高の変 化に伴う周方向展開次数 $\mathrm{N}>1$ の振動モードの固有振動数の変化は大き い。水高が $80 \mathrm{~mm}$ 以上のとき、周方向展開次数 $\mathrm{N}=4$ 、あるいは $\mathrm{N}=3$ の振 動モードがほぼ等しい值をとり、系の最小固有振動数となる。実験から 得られた各振動モードに対応する固有振動数と解析值は良く符合する。 ただし、軸対称モード(周方向展開次数 $\mathrm{N}=0$ ) の実験值は解析值よりか なり小さな固有振動数となる。

同様に、実験応答から特定された周方向展開次数 $\mathrm{N}=0,1,2,3,4,5,6,7$ の各 振動モードに対応する小さい方から2番目の固有振動数 $\omega_{\mathrm{N} 2}(\mathrm{~Hz})$ をFig.42に示す。記号はFig.4-1 と同一の周方向展開次数の振動モードを表す。 周方向展開次数 $\mathrm{N}=1$ の振動モードに関して、両者は十分な精度で符合す る。しかしながら、各周方向展開次数に対応する最小固有振動数の図と 比較すると、小さい方加2番目の固有振動数の実験值と解析値の差異 は大きくなる。この原因を次のように分析している。各周方向展開次数 に対応する2番目の固有振動数の応答が観察されるはずの振動数領域に おいて、さまざまな応答が発生し、いくつかの振動モードが複合した応 答が観測される。これらの応答のモードを特定することが難しく、適切 に特定できなかった振動モードが紛れている可能性がある。

\section{4-1-2 分数調波振動の不安定領域}

外力加速度の実効值が1g、および2gの下における供試体Mv7に生起 した分数調波振動の不安定領域をそれぞれFig.5-1、およびFig.5-2に示 す。これらはすべて $1 / 2$ 倍分数調波振動が主要な振動成分となる不安定 領域である。外力加速度 $1 \mathrm{~g}$ とき、水高 $140 \mathrm{~mm}$ 以上のモデルにおいて、

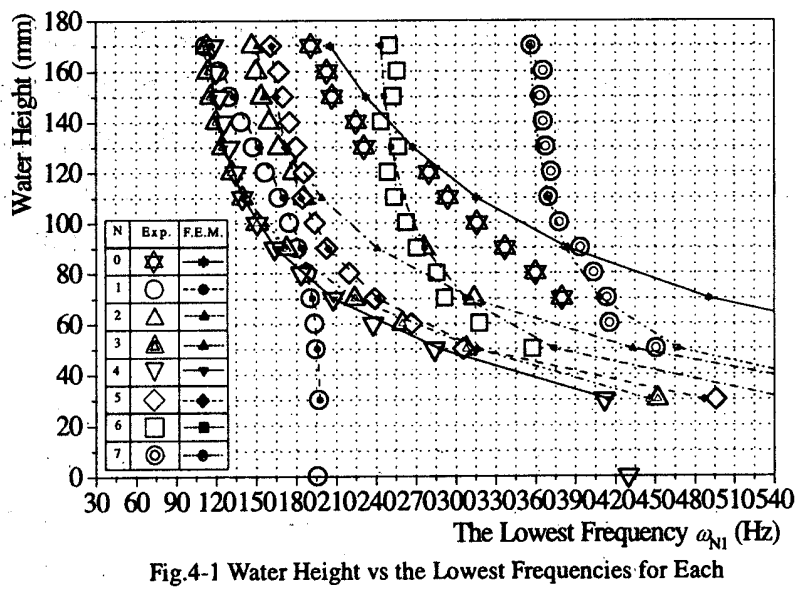
Circumferential Fourier Number N (Mv7)

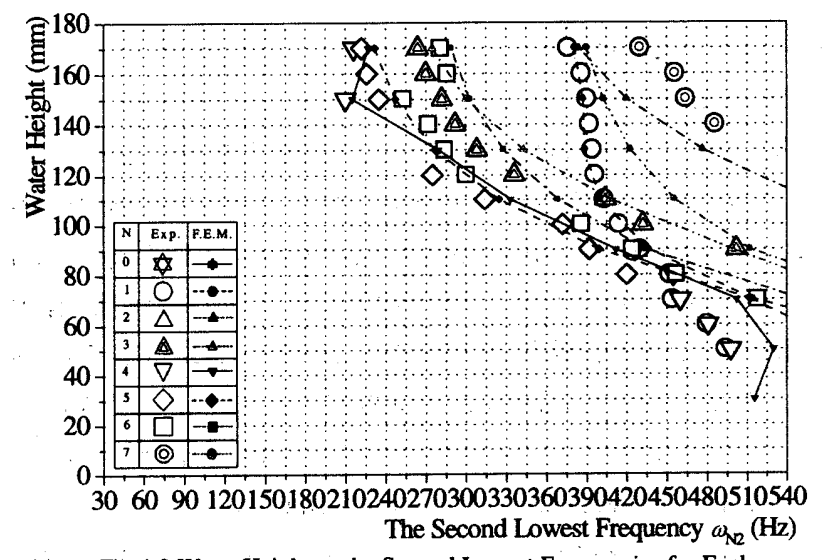

Fig.4-2 Water Height vs the Second Lowest Frequencies for Each Circumferential Fourier Number N (Mv7)
外力振動数が周方向展開次数 $\mathrm{N}=6$ に対忘する振動モードの最小固有振動 数の 2 倍近傍となる振動数領域に、 $\mathrm{N}=6$ の振動モードの $1 / 2$ 倍分数調波 振動が生起する。この領域はFig.5-1において黒色の領城として示した。

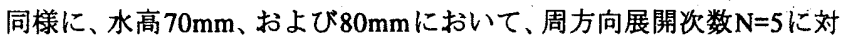
応する振動モードの最小固有振動数の 2 倍近傍となる振動数領域に $\mathrm{N}=5$ の振動モードの1/2倍分数調波振動が生起する。この領域をFig.5-1 において灰色の領域として示した。水高60 mmのモデルにおいて、周方 向展開次数 $\mathrm{N}=4$ の振動モードが分岐する振動数領域がある。この領域を Fig.5-1において白色の領域として示した。また、水高70 mmのモデルに おいて、外力振動数が固有振動数 $\omega_{51}(\mathrm{~Hz})$ と $\omega_{61}(\mathrm{~Hz})$ の和の振動数の近 傍領域において、これらの固有振動数に対応する周方向展開次数を有す るふたつの振動モードが主となる $1 / 2$ 倍分数調波振動、および1/3倍分 数調波振動が生起する。この領域において、1/2倍分数調波振動成分の 応答が $1 / 3$ 倍分数調波振動成分の応答より大きいものの、後者の成分が 必ず含まれる。これをFig.5-1において2重斜線の領域として示した。図 中の不安定領域に隣接する数字は主要な振動モードに対応するひずみの 最大振幅（単位 $\mu$ )を表す。

周方向展開次数 $\mathrm{N}=4,5,6$ 振動モードに対応するそれぞれの最小固有 振動数 $\omega_{41}, \omega_{51}, \omega_{61}$ 、および周方向展開次数 $\mathrm{N}=1$ の小さい方から2番目 の固有振動数 $\omega_{12}$ 用いここれらの固有振動数 $(\mathrm{Hz})$ の簡単な算術式 (図 中の矩形枠内に表示)に対応する折れ線を図中に示す。水高が変化し、 固有振動数が推移するに連れて、分数調波振動の不安定領域も移動して いる。逆に、Fig.5-1、およびFig.5-2に示された不安定領域が生起する条 件を構成する固有振動数、および対応する振動モードの関係をこの不安 定領域の推移は明らかにしている。

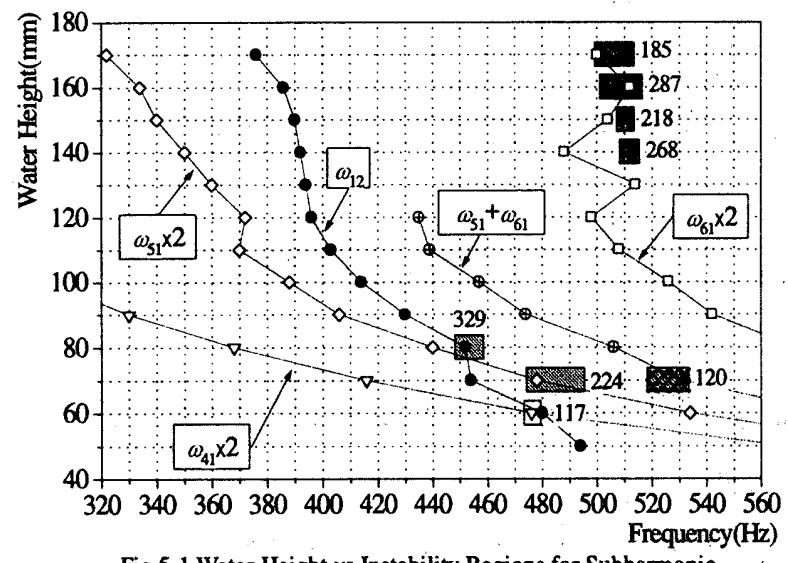

Fig.5-1 Water Height vs Instability Regions for Subharmonic Oscillation Components (Mv7, 1g)

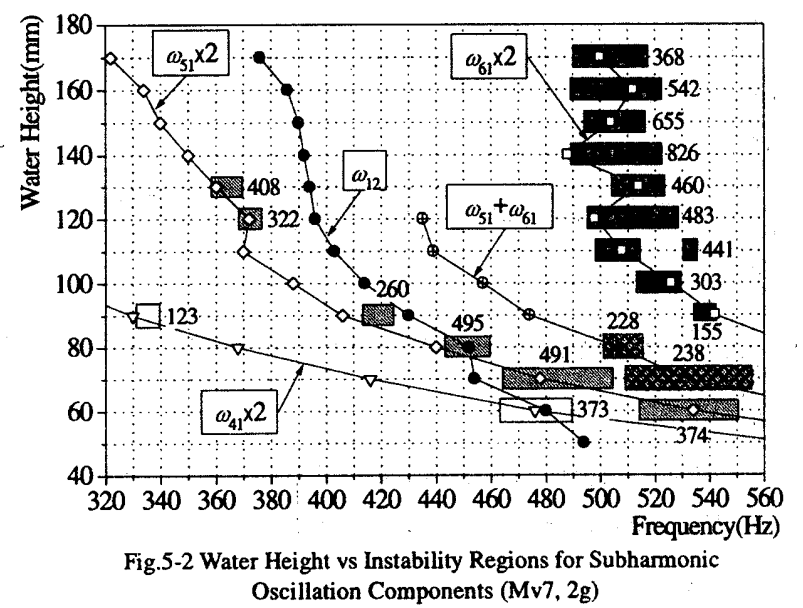




\section{4-2 分数調波振動の不安定領域における振動の分類}

実験に利用した8体の供試体で観測された分数調波振動の不安定領域 は次のような4タイプに大別される。

タイプA: 外力振動数が $\omega_{\mathrm{j} 1}(\mathrm{j}=4,5,6)$ の 2 倍近傍の值をとる時、周方向 展開次数 $\mathrm{N}=\mathrm{j}$ の振動モードを有する $1 / 2$ 倍分数調波振動が生起する領域 である。これ以外の振動モードや他の分数調波振動成分を混入しない忘 答として出現する。混入した $\mathrm{N}=\mathrm{j}$ 以外の振動モードのひずみの最大振幅 と主モードのひずみの振幅との比は0.06-0.15程度である。

不安定領域 $\mathrm{B}$ 外力振動数が $\omega_{51}$ 、および $\omega_{61}$ の和となる振動数近傍にお いて、周方向展開次数 $\mathrm{N}=5$ 、および $\mathrm{N}=6$ の振動モードが連成し、1/2 倍 分数調波振動成分を有する応答が生起する領域である。応答が小さな方 の振動モードのひずみの振幅と応答が大きな方の振動モードのひずみの 振幅との比は0.28-0.41である。外力加速度が増大すると、この不安定領 域内に $1 / 3$ 分数調波振動も分岐する幅の小さな不安定領域が出現する。

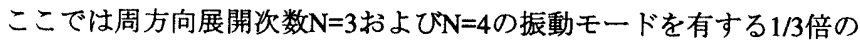
分数調波振動が混入する。この不安定領域をB'と表現する。

不安:定領域 $\mathrm{C}$ 外力振動数が、周方向展開次数 $\mathrm{N}=4$ の最小固有振動数 $\omega_{41}$ の3倍近傍の振動数領域において、 $\mathrm{N}=4$ の振動モードを有する1/3倍 分数調波振動が生起する。この応答が観察された供試体において、的の 3 倍の振動数は $\mathrm{N}=1$ の固有振動数 $\omega_{12}$ に近接していた。

不安定領域 $\mathrm{D}:$ 外力振動数が周方向展開次数 $\mathrm{N}=1$ の固有振動数 $\omega_{12}$ 近傍 において、 $\mathrm{N}=5$ の振動モードを有する1/2倍分数調波振動が主要なモー ドとなり、 $\mathrm{N}=5$ の振動モードを有する1/3倍分数調波振動(0.55-0.96)、お よびN=6の振動モードを有する $1 / 2$ 倍分数調波振動 (0.36-0.75)、N=4の 振動モードを有する $1 / 2$ 倍分数調波振動(0.15-0.34) 等の応答が分岥する。 小括弧内の小数は、実験において観察された各振動モード、および振動 成分のひずみ応答の振幅と主要モードのひずみ応答の振幅の比である。 すなわち、振動モードの連成ばかりでなく、振動成分間にも連成が生ず る不安定領域である。これらの応答が出現する領域にふたつのタイプが 観察された。ひとつはこの不安定領域が周方向展開次数 $\mathrm{N}=1$ 共振領域 と独立と判断された不安定領域 (不安定領域D) である。他方は、この 不安定領域が周方向展開次数 $\mathrm{N}=1$ の固有振動数 $\omega_{12}$ に近接し、この応答

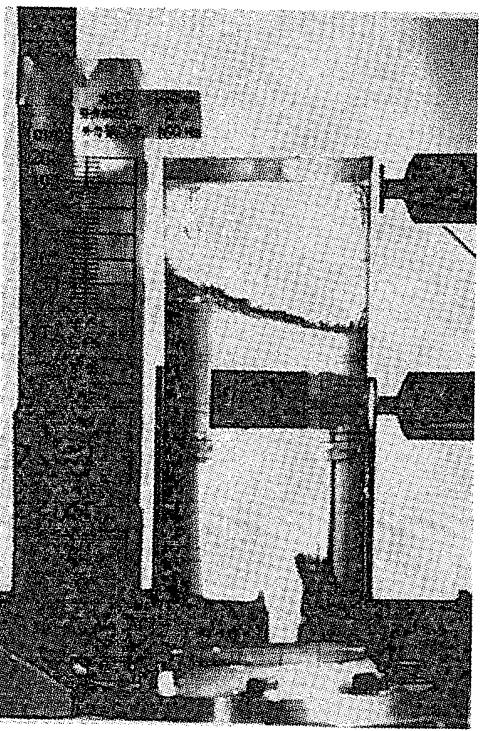

Photo.1 Sloshing under Table Acceleration $2.0 \mathrm{~g}$, External Frequency $160 \mathrm{~Hz}$ (Mv8, Water Height $140 \mathrm{~mm}$ )
が影響していると判断される 領域 (不安定領域D')である。

これら分数調波振動の不安 定領域、出現する振動成分と 振動モード、および観測され た供試体と水高の例を Table. 2 に示した。表中に下 線を付した例は3-2-2、4-1-2で 害及した不安定領域である。

これらの不安定領域のう ち、不安定領域 A、C、および D’における分数調波振動応答 の生起に関しては、円筒タン クとポテンシャル流体の大変 形場における動的相互作用問 題として定式化された理論的 な解析 ${ }^{14)}$ が示されている。
Table.2 Instability Regions of Subharmonic Oscillations

\begin{tabular}{|c|c|c|c|}
\hline $\begin{array}{l}\text { Instability } \\
\text { Region }\end{array}$ & $\begin{array}{l}\text { Subharmonic } \\
\text { Oscillations }\end{array}$ & $\begin{array}{c}\text { Main Mode \& } \\
\text { (Secondary Mode) }\end{array}$ & $\begin{array}{c}\text { Example:Specimen } \\
\text { (height of water:mm) }\end{array}$ \\
\hline \multirow{3}{*}{$\begin{array}{l}\text { Instability } \\
\text { Region A }\end{array}$} & \multirow{3}{*}{$1 / 2$} & 4 & $\mathrm{Mv} 7(60.90)$ \\
\hline & & 5 & Mv7(130),Mv8(130) \\
\hline & & 6 & $\begin{array}{l}\operatorname{Mv5}(130), \operatorname{Mv6}(170), M v 6(130) \\
\operatorname{Mv7(130,170),Mv8(130,170)}\end{array}$ \\
\hline $\begin{array}{l}\text { Instability } \\
\text { Region B } \\
\end{array}$ & $1 / 2$ & $6(5)$ & $\begin{array}{l}\text { Mv1(170),Mv3(170),Mv4(170), } \\
\text { Mv6(130),Mv7(70,80) }\end{array}$ \\
\hline $\begin{array}{l}\text { Instability } \\
\text { Region B' }\end{array}$ & $\begin{array}{l}1 / 2 \\
1 / 3 \\
\end{array}$ & $\begin{array}{c}6(5) \\
3 \text { or } 4\end{array}$ & $\operatorname{Mv3(170),Mv4(170),Mv6(130)~}$ \\
\hline $\begin{array}{l}\text { Instability } \\
\text { Region C }\end{array}$ & $1 / 3$ & 4 & $\mathrm{Mv2(170),Mv3(170)}$ \\
\hline $\begin{array}{r}\text { Instability } \\
\text { Region D }\end{array}$ & $\begin{array}{l}1 / 2 \\
1 / 3 \\
\end{array}$ & $\begin{array}{l}5(6) \\
5(6) \\
\end{array}$ & Mv7(70,80) \\
\hline $\begin{array}{l}\text { Instability } \\
\text { Region D' }\end{array}$ & $\begin{array}{l}1 / 2 \\
1 / 3 \\
\end{array}$ & $\begin{array}{l}5(6) \\
5(6) \\
\end{array}$ & $\begin{array}{l}\text { Mv1(130,170),Mv3(170), } \\
\text { Mv4(170),Mv6(130,170) }\end{array}$ \\
\hline
\end{tabular}

4-3高い外力振動数領域におけるスロッシング振動

スロッシング振動 22,24$)$ は容器が主に振動する領域よりかなり低い振動 数領域に起こる。ここで扱っている円筒タンクにおいては $10 \mathrm{~Hz}$ 以下の 固有振動数を有する。それゆえ、容器が振動する高い外力振動数におい て、水の表面はさざなみ状に挙動すると考えられてきた2)。しかしなが ら、外力振動数が $130 \mathrm{~Hz}$ 以上の領域において波高が6-10mmに達するス ロッシング振動応答が観測された。外力加速度 $2 \mathrm{~g}$ 、外力振動数 $160 \mathrm{~Hz}$ 、 水高 $140 \mathrm{~mm}$ の供試体Mv8において観測された周方向展開次数 $\mathrm{N}=1$ が主 となり、波高振幅が約 $9 \mathrm{~mm}$ となったこの種のスロッシング振動応答を 写真1に例示する。このような外力振動数が高い領域において、水面は さざなみ状を呈するとしていた従来の連成問題の仮定が成立しない応答 である。これらはビート振動として生起するものと考えられる。生起の メカニズムは今後の課題である。

\section{$\S 5$ 結語}

5-1 周期的に振動する振動台に載せられた水の入った円筒タンクの応 答に、高調波振動応答が観測される。外力振動数が各振動モードに対応 する固有振動数の1/2倍、および1/3倍の值となる領域近傍において、こ のモードに対応する2倍、および3倍の高調波振動応答が発生する。 5-2 水の入った円筒タンク応答のうち、1/2倍分数調波振動、および 1/3倍分数調波振動は大きな振幅の振動として、ある振動数領域におい て分岐する応答として出現する。これらの分数調波振動は容器に大きな ひずみを発生させる応答である。この分数調波振動は外力加速度が十分 小さい時はまったく発生しない。ある大きさ以上の外力加速度の下で、 分数調波振動は出現し、この領域は不安定領域を形成する。この不安定 領域は大別すると4種類に分類された。

A: 外力振動数が周方向展開次数 $\mathrm{N}=4 、 \mathrm{~N}=5$ 、およひ $\mathrm{N}=6$ に対态する振動 モードの固有振動数の2倍近傍において、この振動モードを有する1/2 倍分数調波振動が出現する。このタイプの分数調波振動はさまざまな水 高を有するモデルにおいて出現する。これらの振動数領域と周方向展開 次数 $\mathrm{N}=1$ を有する振動モードの固有振動数が近接しているときには、こ のモードの主共振領域においてもこれらの分数調波振動は出現する。 B: 外力振動数が、周方向展開次数 $\mathrm{N}=5$ および $\mathrm{N}=6$ に対灾するそれぞれ の振動モードの固有振動数の和となる振動数近傍において、これらの振 動モードが連成した1/2倍の分数調波振動が出現する。

$\mathrm{C}$ : 外力振動数が周方向展開次数 $\mathrm{N}=4$ の振動モ一ドに対応する固有振動数 の3倍の振動数領域において、周方向展開次数 $\mathrm{N}=4$ の $1 / 3$ 倍の分数謂波 振動が出現する可能性がある。このとき、周方向展開次数 $N=4,5,60$ 振 
動モードを有する1/2倍の分数調波振動も観察される。観測されたこ の応答の不安定領域の出現に周方向展開欢数 $\mathrm{N}=1$ の共振領域が重なっ ている可能性が高い。

D: 外力振動数が周方向展開次数 $\mathrm{N}=1$ の固有振動数 $\omega_{12}$ 近傍において、 $\mathrm{N}=5$ の振動モードを有する $1 / 2$ 倍分数調波振動が主要なモードとなり、 $\mathrm{N}=5$ の振動モードを有する1/3倍分数調波振動、および $=6$ の振動モ一 ドを有する $1 / 2$ 倍分数調波振動、N=4の振動モードを有する $1 / 2$ 倍分数 調波振動等の応答が分岐する。

本論文において周方向展開次数 $\mathrm{N}=4,5,6$ のモードとして観測された分 数調波振動が、タンクの寸法に依存してより高い周方向展開次数の モードとして出現することも有り得る。

5-3 外力振動数が高い領域において、波数の小さいモードを有するス ロッシング振動が大きな振幅の応答として生起する。

これらの知見から、次のような推論が成立するものと思われる。外 力加速度の大きさがある程度以上であり、外力振動数が各周方向展開 次数Nのモードを有する固有振動数の2倍、および3倍の近傍におい て、対応する振動モードの1/2倍、および1/3倍の分数調波振動が生起 し得る。また、外力加速度の大きさがある程度以上であり、外力振動 数が異なる周方向展開次数のモードに対応する固有振動数の和である 領域近傍において、これらふたつの振動モードが連成して生起する $1 / 2$ .倍の分数調波振動が生起し得る。1/2倍の分数調波振動は1/3倍のそれ よりも出現し易いようである。これらの分数調波振動の生起に周方向 展開次数 $\mathrm{N}=1$ のモードの共振領域が影響し、この領域と上記の分数調 波振動が出現する領域が近接するとき、この共振領域においても分数 調波振動が出現する。」これらを実験、あるいは理論解析に基づいて確 認することが、水の入った円筒タンクに生起する非線形振動応答の次 の課題となる。

謝辞 この研究は平成8-10年度科学研究費補助金((基盤研究(C)(2))課 題番号08650678、平成2-3年度科学研究費補助金(一般研究C)課題番 昼02650405、昭和63-平成元年度科学研究費補助金(一般研究C)課題 番号63550416の助成を受けた。海備段階の研究を含めるなら昭和59-60年 度科学研究費補助金 (一般研究C)課題番号59550377.の助成も受けた。

この実験的な研究に15年以上の期間が費やされた。振動台の作製時 から、多くの大学院生、および卒論生の献身的な協力が有って、初め て得られた研究成果である。数が多くて氏名を明示できないものの、 円筒シェル供試体を作製し、寒験を行うだけでも強勒な忍耐力を要求 され、振動現象も理解が難しく、応答を整理する手続きも難解な研究 に携わったこれらの学生に束心より感謝する。

\section{考文献}

1)Clough,R.W.,Niwa,A.,and Clough.D.P.:Experimental Seismic Study of Cylindrical Tanks, Proc.ASCE,vol.105,no.ST12,1979, pp.2565-2597

2) 堀直人、谷凟信、田中狝寿雄: 液体の入った円筒シェルの動的解析、日本 建築学会論文報告集、第 282 号、昭和 54 年 8 月、pp.83-94

3) Haroun,M.A.and Housner,GW.:Dynamic Characteristics of Liquid Storage Tanks: Complications in Free Vibration Analysis of Tanks, Proc.ASCE, Vol.108,No.EM5,1982, pp.783-818
4) 皆川洋一、堂元信宏:液体の入った円筒シェル及び短形容器の水平振動実験、 日本建築学会研究報告 九州支部、第 29 号·1、pp.145-148、昭和 61 年 3 月

5) 皆川洋一液体の入った回転シェルの水平振動へ及ぼす非線形振動の影響の 評価に関する研究、昭和60年度科学研究費補助金(一般研究 $C$ )研究成果報告 集、昭和 61 年 3 月

6) 皆川洋一:有限変形場でのポテンシャル流体と弾性体容器の相互作用を支配 する汎関数、日本建築学会構造系論文報告集第 362 号、pp.105-115、昭和 61 年 4 月

7) 皆川洋一、岩本茂美、堂元信宏:水の入った円筒シェルの水平振動実験、日本 建築学会大会学術講演梗概集 構造I、pp.939-940、昭和 61 年 8 月

8) 皆川洋一、岩本茂美、堂元信宏:水の入った円简シェルの水平振動実験、日本 建築学会研究報告 中国·九州支部、第 7 号・1、pp.121 - 124、昭和 62 年 3 月 9) 皆川洋一、岩本茂美:水の入った円筒シェルの水平振動実験、日本建策学会大 会学術講演梗概集 構造I、pp.1239 - 1240、昭和 62 年 10 月

10) 皆川洋一、岩本茂美 : 水の入った円简シェルの水平振動に関する実験的研 究、鹿児島大学工学部研究報告第 29 号、pp.53-63、昭和 62 年 11 月

11) 皆川洋一、岩本茂美、久保浩一:水の入った円筒シェルの水平振動実験にお ける非線形振動成答、日本建築学会大会梗概集 構造 I、pp.1313－1314、昭和 63 年 10 月

12) 皆川洋一:水の入った円简シェルの水平振動における非線形振動応答の影 帮の評価、平成元年度科学研究費補助金 (一般研究C) 研究成果報告、平成2 年3月

13) 皆川洋一:円筒シェルの水平振動実験における高次振動モードおよび非線 形振動の生起、日本建築学会大会学術講演梗概集 構造I、pp.1233 - 1234、1990 年 10 月

14) Y.Minakawa:Nonlinear Oscillation Analysis of Interaction Behaviors Between the Potential Fluid and Tanks of Shell of Revolution in Finite Deformations 、日本建築 学会構造系論文報告集 No.435、pp.91 - 107、1992 年5月

15）皆川洋一、西秀敏、末広康之:水の入った円简シェルの水平振動実験におけ る非線形振動、日本建築学会大会学術講演梗概集 B 構造 I、pp.927-928、1993 年9月

16) 皆川洋一、末広康之:水の入った円筒シェルの水平振動実験(水位に伴う非 線形振動応答の生起)、日本建築学会九州支部、第35号・1、pp.305-308、1995 年3月

17) 末広康之、皆川洋一:水の入った円筒シェルの水平振動実験 (水高が非線形 振動の生起に及ぼす影響)、日本建築学会大会講演学術講演集、構造 I、 pp553-554、1995年 10 月

18）皆川洋一:水の入った円筒シェルの非線形振動応答、シェル・空間棈造の 自然災害時非線形挙動とその抑止対策論文集、pp.111-124、京都大学、平成 .9 年 10 月

19）野間紀男、上䓵忠敬、皆川洋一:水の入った円筒シェル容器の水平振動実倹 における非線形振動応答、日本建築学会九州支部研究報告、第 38 号・1、 pp.273-276、1999 年3 月

20) 皆川洋一:水の入った円筒タンクの水平振動における非線形振動応答の研 究、平成 4 年度科学研究補助金 (一般研究 C) 研究成果報告書

21) 皆川洋一:水平地動を受ける水の入った円筒タンクにおける非線形振動応 答に関する研究、平成 8-10 年度科学研究補助金((基盤研究 $(C)(2))$ 研究成果 報告書

22) 本村憲明、大橋弘隆 : 軸対称容器におけるスロッシングの非線形応答、日 本機械学 会論文集、第一部、第 385 号、1978、pp.3024-3033

23) 池田駿介、秋山成興、中村広昭、白井伸一:円筒タンクの液体動摇に関す る研究、士木学会論文報告集、第 290 号、1979 年 10 月、pp.53-65 24) 大森博司、松井徹哉、日比野浩:液体貯槽の有限振幅液面動摇に関する研 究、日本建築学会構造系論文報告集、第375号、1987 年5月、pp.65-72

（1999年 7 月 10 日原稿受理, 1999 年12月 9 日採用決定 